\title{
REVIEW
}

\section{Hubert Wolf \\ Pope and Devil: \\ The Vatican's Archives and the Third Reich}

\author{
Kenneth Kronenberg, Translator
}

(Cambridge: Belknap Press of Harvard University Press, 2010), hardcover, 325 pp.

Suzanne Brown-Fleming, Center for Advanced Holocaust Studies, United States Holocaust Memorial Museum

In February 2003, in an unprecedented break with Vatican Secret Archives policy, the Holy See opened those records pertaining to the Munich and Berlin nunciatures (Vatican diplomatic headquarters) for the period 1922 to 1939. During these years, Eugenio Pacelli, the future Pope Pius XII (1939-1958), served as nuncio to Bavaria and Germany (1917-1929) and Secretary of State to Pope Pius XI (1930-1939). In 2006, Pope Benedict XVI released "about 100 thousand [additional] archival units, each containing up to a thousand pages" when he opened all files in the Vatican secret archive relating to the pontificate of Pope Pius XI (p. 309).

In Pope and Devil, Wolf, accessing these new sources, analyzes the "view from Rome" on five general areas, broken into five individual chapters: (1) the Vatican Secretariat of State's (and Pacelli's) aims and goals in Germany from 1917-1929; (2) Amici Israel and the ugly circumstances surrounding the March 1928 Holy Office decree on anti-Semitism (see p. 82); (3) the role played by Pacelli and Pius XI in the fraught months between January and July 1933, the period of the Enabling Act, the retraction of the Mainz Declaration, and the concordat between the Holy See and Nazi Germany; (4) Pacelli, Pius XI, and the persecution of Jews, focusing on 1933 and 1938; and (5) the relationship between Catholic worldview and Nazi ideology from 1933 to 1939.

Wolf cites four schools of thought that have emerged regarding Catholic attitudes toward Jews: (1) the "resistance thesis," that "because of their faith Catholics fundamentally rejected National Socialism along with its racial theories"; (2) the "indifference thesis," that "the majority of Catholics were neither for nor against Jews"; (3) Olaf Blaschke's model of "endogenous Catholic antiSemitism," that "Catholics needed Jews as a 'scapegoat' to stabilize the Catholic milieu"; and, finally, (4) the "ambivalence thesis," that "although Catholics distanced themselves from 'racial' anti-Semitism, they did not reject all anti-Semitism, but instead supported the 'better' Christian anti-Semitism" (p. 119, quoting Urs Altermatt, Katholizmus und Antisemitismus. Mentalitäten, Kontinuitäten, Ambivalenzen. Zur Kulturgeschichte der Schweiz, 1918-1945, Frauenfeld: Huber [1999], p. 51). Wolf characterizes the evidence he brings forth as fitting most closely with the "ambivalence thesis," especially the 1928 debates concerning Amici Israel.

Wolf is especially interested in Pacelli's motivations. For example, Wolf argues that Pacelli's failure to secure an armistice in World War I in 1917 drove his subsequent rejection of "all calls for [Vatican] intervention in such conflicts," and led him to firmly embrace instead his mentor Pietro Gasparri's conviction "that the Holy See... remain absolutely neutral in political and military conflicts" (p. 43). As nuncio to Bavaria and Germany (1917-1929), Pacelli believed in a 
"Rome-centered model of the church," codified in the 1917 Codex luris Canonici, and strongly critiqued German Catholic intellectuals who "rejected the Church of law, instead holding forth for a Church of love" (p. 62). Pacelli was, as a July 1933 article in the German Social Democratic newspaper for the Saar region Volksstimme called him, a leader of "the compromise camp." Wolf writes that Pacelli took the position of "strict neutrality for the Holy Father in all political controversies, which for [Pacelli] included the Jews" (p. 212). In September 1941, in a letter available to scholars since 1966, Pacelli wrote to Bishop Preysing to comment, among other things, on the August 1941 anti-euthanasia sermons by the bishop of Münster: "the Church in Germany is all the more dependent on your public action, as the general political situation in its difficult and frequently contradictory particularities imposes the duty of restraint on the supreme head of the entire church in his public proclamations" (p. 222). Behind the scenes, Pacelli was a master political tactician, as so intriguingly demonstrated by Wolf in his discussion of the 1927 Holy Office ban on German Catholic participation in ecumenical activities just as Pacelli was negotiating the Prussian concordat (pp. 232-245).

Wolf says Pacelli disapproved of German right-wing anti-Semitism yet was susceptible to antiSemitic stereotypes. Wolf does not provide new evidence on this score, citing two documents: Pacelli's April 30, 1919 reference to "grim Russian-Jewish-revolutionary tyranny" in describing the Second Soviet Republic in Bavaria (April 12-May 3, 1919) (p. 79), and the much-discussed April 1919 report about the Munich revolutionaries from Pacelli to Gasparri, which first appeared in Emma Fattorini's 1992 book Germania e Santa Sede: La Nunziature di Pacelli tra la Grande Guerre e la Reppublica di Weimar (Bologna: Societa Editrice il Mulino), and became sensationalized by Cornwell's reference to it in his highly-critiqued 1999 book Hitler's Pope: The Secret History of Pius XII (New York: Penguin).

Some cases brought to light for the first time are heartbreaking. On April 9, 1933, Viennese Rabbi Arthur Zacharias Schwarz wrote to Pope Pius XI in the latter's capacity as pope but also on the basis of a long-time scholarly and personal relationship, which was deeply meaningful to the rabbi according to his letter. "Your Holiness can hardly know the effect that a word coming from Your Supreme Person would have on pious Jews, who, like me, reject all radicalism. If it were possible for Your Holiness to express that the injustice committed against the Jews remain an injustice [emphasis in original], such a word would lift up the courage and morale of millions of my Jewish brethren," wrote Rabbi Schwarz to his long-time acquaintance. Rabbi Schwarz enclosed this letter in one to Pacelli, with the request that Pacelli "be so good as to convey it to His Holiness," and explained their history together, dating back to 1907. Pacelli, writes Wolf, "never gave [Pius XI] the rabbi's petition." Rabbi Schwarz was arrested and tortured by the Gestapo after the annexation of Austria. He died in Palestine in February 1939 (pp. 192-195).

For the specialist, there are many gems in this book: Pacelli's unflattering opinion of Adolf Cardinal Bertram, chair of the Fulda Bishops Conference (pp. 48-50); Pacelli's direct hand in installing his favorite, Konrad von Preysing, as bishop of Berlin in 1935, so as to act as Pacelli's "liaison to the German episcopate and to the government of the Reich" (pp. 55-59); and Pacelli's love for his custom-built Mercedes Benz, received as a gift from Center Party Chair Matthias Erzberger when Pacelli arrived in Munich in May 1917, complete with papal coats of arms on the door mountings (p. 76). Those scholars eager to cite the supposedly enlightened views of Jews and Judaism on the part of Pope Pius XI will want to read carefully chapter two and the May 1928 commentary in Civilità Cattolica, "Il pericolo Giudaico e gli 'Amici d'Israele,"' printed at the direct behest of the pope and featuring adjectives like "presumptuous and powerful" and "danger[ous]" to describe Jews (p. 116). Pius XI, we now know due to evidence brought forth by Wolf, explicitly supported the retention of "perfidious Jews" in the Good Friday liturgy (p. 121). Wolf duly notes Pius XI's very different position ten years later, when in 1938 he "tried in concrete ways to assist 
persecuted Jewish in Germany, Austria and Italy," and, better known, his statements during an audience with Belgian pilgrims in September 1938 (pp. 206-08). Nonetheless, Wolf implicitly critiques Pius XI as someone who erred on the wrong side of what he calls the "typically Roman compromise between dogma and diplomacy" (pp. 269-70), with diplomacy consistently winning the day.

Wolf's discussion of the famous encyclical Mit Brennender Sorge is particularly interesting in this respect. The newly released materials demonstrate the extent to which years-long discussions, deliberations, and written texts by consultors in the Holy Office regarding placing Mein Kampf on the Index of Forbidden Books made their way into the text and spirit of Mit Brennender Sorge. Wolf writes that the "dangerous opinions to be found in Mein Kampf had been refuted in the syllabus of the Congregation of Studies and contrasted to the true Catholic doctrine in the encyclical Mit Brennender Sorge. In this respect, the pope met the requirements of pure doctrine. Nonetheless, he was not prepared to name names because he was unable and unwilling to attack the führer and Reich Chancellor [Adolf Hitler] personally" (p. 270).

Wolf's flair for sharp narrative engages and even provokes the reader: "For Pacelli, the bishops were little more than papal head altar boys, called on to act only on the instructions of the pope...Rome wanted yes-men with child-like devotion to the Holy Father. This was Pacelli's crucial criterion for a good bishop, and he bent every effort to install just such men and to stamp out the independence of the German church" (p. 74). Wolf is unsparing in describing the cowardice of Abbot Ildelfons Schuster in revoking his opinion submitted to the Congregation of Rites that the Good Friday prayer be reformed (pp. 114-115). Wolf remarks that "Christian or Catholic antiSemitism" is "usually called anti-Judaism to make it more palatable" (p. 119). At one point he sums up Pius XI as having "wasted his big chance," adding unflinchingly that "it took decades and more than six million murdered Jews for the Church to summon the courage to cleanse its relationship with the Jews of anti-Semitism, even in the liturgy" (p. 121). Wolf concludes his book with the following brutal sentence: "Hitler remained a member of the Catholic Church until the day he died. Like the pope, even the devil could be Catholic" (p. 271).

Most fascinating is Wolf's argument that two 1928 articles by Jesuit Enrico Rosa mark the birth of a still-highly-problematic debate within church and scholarly circles today. The first is the aforementioned one in Civilita Cattolica and the second the essay "Semitismo e antisemitismo" in L'Avvenire d'Italia (May 1928), which distinguished between "evil, biologically motivated racial anti-Semitism" rejected by the Church, and supposedly "good" theologically motivated antiSemitism (p. 117). Anti-Judaism (Father Rosa's "good" anti-Semitism) is understood as prejudice against Jewish peoples based on their distinctive religious practices, resulting in political and legal measures against the practice of Judaism and the social and civil rights of Jews themselves. Dating back to the pre-Christian Greco-Roman world, some understand it as a precursor to-but distinctive from-anti-Semitism, the term coined in the writings of German journalist Wilhelm Marr in 1879 to describe hostility toward Jews on the basis of biological, political, cultural, and economic differences between Jews and their gentile neighbors in an increasingly secularized Europe. Others, including Kevin Spicer and this author, argue that centuries-old anti-Judaism and $19^{\text {th }}$-century-born anti-Semitism, while distinctive from one another in the root causes of their anti-Jewish animosity, differ not at all in their deadly effect on Jews.

Wolf recognizes the limits of his study. Scholars still have "little understanding of the popes' stance toward the persecution of the Jews and the Holocaust" (p. 309). It is, he says, "too early to render a judgment" (p. 17). It will "take years, if not decades, of responsible archival research to develop the understanding" that might make comprehensive analysis of the Vatican-National Socialist relationship possible" (p. 309). At one point, Wolf remarks that the Curia "had little 
scope...to achieve anything, even in individual instances [when aid was requested on behalf of Jews]." He continues, "The question of how beneficial in practice a public declaration by the pope would have been must at least be raised" ( $p$. 199). While Wolf may be correct to question real-time positive effects of a papal denunciation of Nazi anti-Jewish measures specifically, the effect on subsequent generations of post-World War II Catholics would have meant the ability to be proud of the Nazi-era record of one's institution, rather than ashamed.

Note: The views as expressed are the author's alone and do not necessarily represent those of the United States Holocaust Memorial Museum or any other organization. 